\title{
The depuration dynamics of oysters (Crassostrea gigas) artificially contaminated with hepatitis A virus and human adenovirus
}

\author{
Adriana de Abreu Corrêa ${ }^{1,2}$, Caroline Rigotto ${ }^{1,2}$, Vanessa Moresco ${ }^{1,2}$, \\ Cristian Rafael Kleemann ${ }^{1,2}$, Adriano Luiz Teixeira ${ }^{1,2}$, Carlos Rogério Poli ${ }^{4}$, \\ Cláudia Maria Oliveira Simões ${ }^{1,3}$, Célia Regina Monte Barardi ${ }^{1,2} /+$
}

\author{
'Laboratório de Virologia Aplicada ²Departamento de Microbiologia, Imunologia e Parasitologia, Centro de Ciências Biológicas \\ ${ }^{3}$ Departamento de Ciências Farmacêuticas, Centro de Ciências da Saúde, Universidade Federal de Santa Catarina, \\ Florianópolis, SC, Brasil ^Blue Water Aquaculture Ltda, Florianópolis, SC, Brasil
}

\begin{abstract}
Within the country of Brazil, Santa Catarina is a major shellfish producer. Detection of viral contamination is an important step to ensure production quality and consumer safety during this process. In this study, we used a depuration system and ultraviolet (UV) disinfection to eliminate viral pathogens from artificially infected oysters and analysed the results. Specifically, the oysters were contaminated with hepatitis A virus (HAV) or human adenovirus type 5 (HAdV5). After viral infection, the oysters were placed into a depuration tank and harvested after 48, 72 and $96 \mathrm{~h}$. After sampling, various oyster tissues were dissected and homogenised and the viruses were eluted with alkaline conditions and precipitated with polyethylene glycol. The oyster samples were evaluated by cell culture methods, as well as polymerase chain reaction (PCR) and quantitative-PCR. Moreover, at the end of the depuration period, the disinfected seawater was collected and analysed by PCR. The molecular assays showed that the HAdV5 genome was present in all of the depuration time samples, while the HAV genome was undetectable after $72 \mathrm{~h}$ of depuration. However, viral viability tests (integrated cell culture-PCR and immunofluorescence assay) indicated that both viruses were inactivated with 96 h of seawater recirculation. In conclusion, after $96 \mathrm{~h}$ of UV treatment, the depuration system studied in this work purified oysters that were artificially contaminated with HAdV5 and HAV.
\end{abstract}

Key words: aquaculture - depuration - food safety - shellfish - viruses

The consumption of bivalve mollusc shellfish that are infected with human pathogenic viruses is associated with a number of human diseases, particularly when raw oysters are ingested (Myrmel et al. 2004). Because they are filter feeders, shellfish can adsorb and concentrate the viral particles; for example, if the consumed water is contaminated with human faeces, viral pathogens and bacteria may become trapped within the shellfish (Croci et al. 2007). Oysters, clams and mussels are the predominant carriers for seafood-borne diseases because they are filter feeders and can directly adsorb the particles; moreover, these foods are often consumed raw or undercooked (Murchie et al. 2005).

Globally, more than a billion people rely on seafood as their main source of animal protein and contaminated seafood is a frequent aetiology of diseases contracted from the ocean, including both pathogenic and chemical contamination (Fleming et al. 2006). Traditionally, coliform bacteria and Escherichia coli are measured as indicators of microbiological infection of shellfish and

Financial support: $\mathrm{CNPq}(471565 / 2006-7)$ (to AAC, CRK, VM, CMOS, CRMB), MAPA/CNPq (578200/2008-2), AECID (A/017172/08)

CR was supported by CAPES with a PDEE scholarship program.

+ Corresponding author: cbarardi@ccb.ufsc.br

Received 17 March 2011

Accepted 14 July 2011 monitoring shellfish contamination by probing for the presence of these bacteria has successfully prevented shellfish-borne infections caused by faecal bacteria. However, monitoring shellfish bacterial contamination does not always detect viral contamination (FormigaCruz et al. 2003). Human health problems associated with contaminated shellfish ingestion have been described and viral contamination has been linked to numerous episodes of gastroenteritis, as well as outbreaks of various illnesses (Fleming et al. 2006).

Farming shellfish from areas with low contamination levels can decrease the risk of illness. The risk may be further reduced by treating the shellfish after harvesting, for example with depuration (Richards et al. 2010). Depuration is a commercial practice where the harvested shellfish are placed in tanks filled with clean seawater for several hours to allow the shellfish to filter and their purge contaminants (Rodrick \& Schneider 2003, Croci et al. 2007). This method reduces the levels of microorganisms present in mollusc tissue, thus decreasing the potential for infections that are associated with shellfish ingestion.

Many reports have indicated that purification can effectively eliminate bacterial pathogens (Rodrick \& Schneider 2003, Corrêa et al. 2007). However, studies with enteric viruses, such as hepatitis A virus (HAV), noroviruses and human adenovirus (HAdV) have shown that it is more difficult to remove viruses from the infected oysters (Hernroth \& Allard 2007, Ueki et al. 2007). Previous data have reported that the viruses are mainly concentrated in the digestive gland of the bivalves (For- 
miga-Cruz et al. 2003, Hernroth \& Allard 2007) and, as a result, viral contamination analysis has usually been restricted to this organ. However, viruses can also be absorbed by other tissues, such as the gills and labial palps (Wang et al. 2008). Thus, the analysis of other organs may be important for evaluating shellfish viral contamination and assessing the risk of illness after ingestion.

Extensive improvements have been made in the molecular techniques used to detect enteric viruses in environmental samples. The polymerase chain reaction (PCR) method has become a major tool for virus detection and several studies have shown that PCR can detect fastidious viruses isolated from water samples and molluscs (Jothikumar et al. 2005, Ko et al. 2005, Rigotto et al. 2005, Sincero et al. 2006). However, PCR only detects the presence for viral genomes, which does not yield any information about viral infectivity. Thus, a positive PCR result only indicates whether the virus was once present, not whether the virus is still pathogenic. Therefore, both conventional cell culture methods and PCR amplification assays are needed to assess viral infectivity. The integrated cell culture-PCR (ICC-PCR) assay combines selective enumeration of infectious viruses with rapid and sensitive detection.

Within Brazil, Santa Catarina (SC) has excellent geographical conditions for culturing marine organisms and is, therefore, a major mollusc producer, especially for bivalve molluscs such as the Crassostrea gigas oyster species (Oliveira-Neto 2005). Although depuration is not yet an established practice in Brazil, it is common in European countries and the United States. To expand commercial bivalve mollusc culture in Brazil, a safe product with high commercial value must be guaranteed. In this study, we used molecular, cell culture and immunological methods to study the efficacy of viral elimination via a commercial oyster depuration system. The system was designed by an aquaculture company (Blue Water Aquaculture Ltda, Florianopólis, SC, Brazil) and its efficacy in eliminating bacterial pathogens has been previously described (Corrêa et al. 2007).

\section{MATERIALS AND METHODS}

Viruses and cells - The HAV (strain HM 175) was propagated in a continuous line of foetal FRHk-4 cells (Sincero et al. 2006) and the HAdV5 was propagated in Hep-2 and A549 cells (Rigotto et al. 2005). The cells were cultured in Eagle's minimal essential medium (MEM) (Cultilab, Campinas, SP, Brazil) supplemented with $10 \%(\mathrm{v} / \mathrm{v})$ foetal bovine serum (FBS) (Gibco-BRL, Life Technologies do Brazil Ltda, SP, Brazil), streptomycin $(100 \mu \mathrm{g} / \mathrm{mL})$, penicillin $\mathrm{G}(100 \mathrm{U} / \mathrm{mL})$ and amphotericin B $(0,025 \mu \mathrm{g} / \mathrm{mL})$ (Gibco-BRL).

An indirect immunofluorescence assay (IFA) was used to determine the HAV virus titre as previously described (Barardi et al. 1999), while the TCID50 assay was used to determine the HAdV5 titre (Reed \& Muench 1938).

Oysters, seawater and depuration system - The pacific oysters $(C$. gigas) and ocean water were acquired from an oyster farm located in Florianópolis.

The depuration tank is a closed system that re-circulates seawater. The system was designed by the Blue Water Aquaculture Company and is located at the oys- ter farm where the oysters were harvested. The tank can hold $1,000 \mathrm{~L}$ of seawater and 2,400 oysters in 15 perforated plastic baskets that are divided between three floors. The water is distributed through a pump at a rate of 2,200 L/h. The sterilising system consists of one $18 \mathrm{~W}$ ultraviolet (UV) $(254 \mathrm{~nm})$ low-pressure tube, a sand filter and a refrigeration system. The perforated plastic baskets were kept in a plastic basin with a grid base to avoid recontamination by particulate matter that was released from the oysters. The temperature of the depuration system was maintained at $19-20^{\circ} \mathrm{C}$ during all of the experiments to prevent the molluscs from spawning.

Artificial contamination and depuration assay - Prior to the depuration experiment, a dozen oysters were placed in a tank containing $5 \mathrm{~L}$ of seawater. The seawater was seeded with $3 \times 10^{3}$ viral particles of each selected virus and the oysters were allowed to filter and concentrate the seeded virus for $3 \mathrm{~h}$ as previously described (Sincero et al. 2006). After $3 \mathrm{~h}$, the oysters were removed from the tank and the shells were disinfected with a $0.5 \%$ aqueous chlorine solution for $10 \mathrm{~min}$. After shell disinfection, three oysters were kept as non-depurated controls (time $0 \mathrm{~h}$ ). The remaining oysters were labelled with red ink and immersed in the depuration tank with the uncontaminated oysters.

The depuration assays were performed for a total of $96 \mathrm{~h}$. Three artificially contaminated oysters were harvested at $0 \mathrm{~h}, 48 \mathrm{~h}, 72 \mathrm{~h}$ and $96 \mathrm{~h} ; 2 \mathrm{~L}$ of seawater was collected from the depuration tank at $96 \mathrm{~h}$ to assess if the virus was present in the water at the end of the assay. Uncontaminated oyster samples were also collected before and after each time point as negative controls. At the end of each depuration assay, the water was discharged into the sewage system. The water temperature was monitored at the time of sampling and the seawater was sterilised only with UV radiation during the depuration process. Each depuration assay was repeated three times using the same tank for three weeks (1 experiment per week). At each sampling time, one sample per floor was randomly collected.

Sample processing and nucleic acid isolation from contaminated oyster tissue - After sampling, the oyster shells were opened at the hinge with a sterile oyster knife. The oysters were dissected and the digestive tissue, mantle, gills, labial palps and haemolymph were extracted. The viral particles were recovered from the tissue via an elution/precipitation method previously described (Sincero et al. 2006). Briefly, the solid-adsorbed viruses were eluted from $2 \mathrm{~g}$ of each tissue homogenate and $2 \mathrm{~mL}$ of the haemolymph (corresponding to tissues derived from 3 dissected oysters) by resuspension in $10 \mathrm{~mL}$ of tryptose phosphate broth dissolved in $0.05 \mathrm{M}$ glycine $\mathrm{pH}$ 9.0. The homogenate was purified with an equal volume of chloroform-butanol (1:1) and centrifuged at $13,500 \mathrm{~g}$ at $4^{\circ} \mathrm{C}$ for $15 \mathrm{~min}$. Viruses in the supernatant were precipitated with $12 \%$ polyethylene glycol (PEG) 6,000, dissolved in $0.75 \mathrm{M} \mathrm{NaCl}$ for $2 \mathrm{~h}$ at $4^{\circ} \mathrm{C}$ and centrifuged at $13,500 \mathrm{~g}$ at $4^{\circ} \mathrm{C}$ for $20 \mathrm{~min}$. Each pellet was resuspended in $3 \mathrm{~mL}$ of ultrapure water and extracted twice with $30 \%$ chloroform. 
The viral nucleic acids were extracted from $400 \mu \mathrm{L}$ of each sample as described by Boom et al. (1990). This procedure is based on the use of guanidinium thiocyanate for nucleic acid extraction followed by adsorption to silica particles. Oysters artificially contaminated with known concentrations of HAdV-5 and HAV were used as positive controls to assess for the presence of inhibitors.

Water sampling - The seawater viral concentration was quantified by adsorption of the seawater to an electronegative membrane and subsequent elution, as described by Katayama et al. (2002). Two litres of seawater collected from the depuration tanks after depuration were filtered using a vacuum pump fitted with a type AP20 membrane and subsequently filtered using a type HA $0.45-\mu \mathrm{m}$ negatively charged membrane filter (Millipore Corporation, Bedford, MA, USA). The membrane was subsequently rinsed with $350 \mathrm{~mL}$ of $\mathrm{H}_{2} \mathrm{SO}_{4}(0.5 \mathrm{mM}, \mathrm{pH} 3.0)$ to remove the cations and the adsorbed viruses were eluted from the membrane with $10 \mathrm{~mL}$ of $\mathrm{NaOH}(1 \mathrm{mM}, \mathrm{pH} 10.8)$. The membrane was recovered in a tube containing $50 \mu \mathrm{L}$ of $\mathrm{H}_{2} \mathrm{SO}_{4}(50 \mathrm{mM}, \mathrm{pH} 1.0)$ plus $50 \mu \mathrm{L}$ of $100 \mathrm{X}$ TE buffer, $\mathrm{pH} 8.0$, to neutralise the reaction. The filtrate was concentrated with a Centriprep system (Millipore Corporation, Bedford, MA, USA) at 3,500 $\mathrm{g}$ for $2 \mathrm{~min}$. The final sample volume was $2.0 \mathrm{~mL}$ and $400 \mu \mathrm{L}$ of sample was used for nucleic acid extraction and nested-PCR analysis.

Cytotoxicity assays - Hep-2, A549 and FRhK-4 cell line monolayers $\left(2 \times 10^{5}\right.$ cells $\left./ \mathrm{mL}\right)$ were prepared in 24 well microplates (Corning, Corning, NY, USA) $24 \mathrm{~h}$ prior to each experiment. The cells were washed with phosphate buffered saline (PBS), inoculated with $250 \mu \mathrm{L}$ a two-fold serial dilution (1:2-1:32) of virus in serumfree MEM of unseeded oyster extracts and incubated at $37^{\circ} \mathrm{C}$. All of the assays were done in duplicates. The cells were washed with PBS and inoculated with $250 \mu \mathrm{L}$ of a two-fold serial dilution of oyster extract diluted in serum-free MEM supplemented with $1 \%$ FBS was added to the cells. The plates were incubated and examined for cytotoxic effects after $24 \mathrm{~h}, 48 \mathrm{~h}$ and $72 \mathrm{~h}$ for the Hep-2 and A549 cells and up to a week for the FRhK-4 cells. At each time point, the test cells were compared with the negative controls (no oyster extract). The cell monolayers were observed with inverted light microscopy and stained with a naphthol blue black stain $0.1 \%$ and $5 \%$ acetic acid to identify a non-cytotoxic dilution of the oyster extracts, which would subsequently be used in the virus viability tests (ICC-PCR and IFA).

$I C C-P C R$ - For the ICC-PCR assay, Hep-2 and FrhK-4 cell monolayers were prepared in 24-well microplates as described. The depurated oyster extracts and the positive controls (HAdV5 and HAV) were diluted in non-cytotoxic maintenance medium. The mixture was incubated for $1 \mathrm{~h}$ at $37^{\circ} \mathrm{C}$ with a previously PBS-washed cell-layer to allow for adsorption of the virus and the non-infectious viruses were removed by washing three times with PBS. After incubation, the plates were maintained at $37^{\circ} \mathrm{C}$ for three days for HAdV5 and seven days for HAV detection. The plates were subsequently submitted to three cycles of freeze/thaw to lyse the cells and release the virus particles. The supernatant was recov- ered and $0.4 \mathrm{~mL}$ of sample was used for genome isolation and nested-PCR detection.

IFA - A549 cells were grown to confluence $\left(5 \times 10^{5}\right.$ cells $/ \mathrm{mL}$ ) in an eight-chamber tissue culture slide (LabTek Nunc, Naperville, IL, USA). After treatment with PEG and chloroform, the oyster samples were treated with antibiotics and antifungal agents (penicillin $G$ $100 \mathrm{U} / \mathrm{mL}$, streptomycin $100 \mu \mathrm{g} / \mathrm{mL}$ and amphotericin B $0.25 \mu \mathrm{g} / \mathrm{mL}$ ). Aliquots containing $50 \mu \mathrm{L}$ of each sample, at a non-toxic dilution, were inoculated in each chamber and incubated at $37^{\circ} \mathrm{C}$ for $90 \mathrm{~min}$ to allow for virus adsorption. The inoculum was subsequently removed and $300 \mu \mathrm{L}$ of maintenance medium (the same used for cell growth but with $2 \% \mathrm{FBS}$ ) was added to the infected cells. The slides were then incubated for three days at $37^{\circ} \mathrm{C}$ in a humidified $5 \% \mathrm{CO}_{2}$ atmosphere. After this period, the medium was removed and the cell monolayers were washed twice with PBS. The cells were fixed twice in $100 \%$ methanol at $20^{\circ} \mathrm{C}$ for $5 \mathrm{~min}$ (each fixation) and then air-dried.

The fixed slides were rehydrated for $5 \mathrm{~min}$ in PBS and incubated with $300 \mu \mathrm{L}$ of PBS (for each chamber) containing 1\% bovine serum albumin (Fluka, Steinheim, Germany) (w/v) and 0.05\% (v/v) Tween-20 (blocking solution) for $15 \mathrm{~min}$. Each chamber was incubated with a 1:200 dilution of MAb 8052 (a monoclonal antibody that is specific for a HAdV neutralising epitope) (Chemicon International Inc, Temecula, CA, USA) at $37^{\circ} \mathrm{C}$ for $60 \mathrm{~min}$ in blocking solution. The slides were washed and stained with a goat anti-mouse immunoglobulin G conjugated to fluorescein isothiocyanate (FITC) (Sigma-Aldrich, St. Louis, MO, USA) (1:100 dilution in blocking solution) for $15 \mathrm{~min}$. The FITC-stained cells were then washed and the slides were properly mounted for immersion and examined using epifluorescence microscopy (Olympus BX40, Olympus Inc, New York, USA) with a filter and beam splitter for blue-green excitation at $480 \mathrm{~nm}$. The virus viability was determined by counting the number of fluorescent cells.

Reverse transcription - For HAV cDNA synthesis, a $5.0-\mu \mathrm{L}$ aliquot of RNA was heated to $99^{\circ} \mathrm{C}$ for $5 \mathrm{~min}$, followed by snap cooling on ice for $2 \mathrm{~min}$. Reverse transcription from the denatured RNA was performed with a random primer (hexamer $\mathrm{pd}(\mathrm{N})_{6}-50 \mathrm{~A}_{260}$ units) (Amersham Biosciences, Buckinghamshire, UK) and M-MLV reverse transcriptase (Invitrogen ${ }^{\mathrm{TM}}$, CA, USA) according to the manufacturer's recommendations.

Qualitative PCR - For HAdV5 detection in the water and oyster samples, the oligonucleotide primer pairs (Invitrogen Brazil, Life Technologies, São Paulo, SP, Brazil) hexAA 1885/hexAA 1913 and nehexAA 1893/nehexAA 1905 were used with the PCR amplification conditions described by Allard et al. (2001). The expected size of the PCR product was $300 \mathrm{bp}$ and $142 \mathrm{bp}$ for nested PCR.

The HAV oligonucleotide primer sequences and amplification conditions used were previously described (de Paula et al. 2004). HAV RNA was detected by nested realtime-PCR (RT-PCR) using the F6 (+) and F7 (-) oligonucleotide primer pairs, which amplify all HAV genotypes and produce a 392-bp fragment. The internal primers used were F8 (+) and F9 (-), which amplify a 247-bp fragment. 
The amplicons of both the HAdV5 and HAV seeded water and oyster samples were visualised by standard gel electrophoresis, where $10 \mu \mathrm{L}$ of the final reaction was run on a $1 \%$ agarose gel that was stained with $1 \mu \mathrm{g} /$ $\mathrm{mL}$ ethidium bromide.

Quantitative PCR ( $q P C R$ ) - qPCR was performed to quantify the HAdV5 genome in samples from artificially contaminated oysters that were treated with the depuration system. The HAdV5 genome was quantified from various oyster tissues (e.g., the digestive tissue, mantle, labial palps, gills and haemolymph) at various time points to evaluate the kinetics of viral depuration in several oyster tissues during the depuration process. The oyster tissues were processed and the nucleic acids were isolated as described. A TaqMan assay was performed with the oligonucleotides, probe and amplification conditions previously described by Hernroth et al. (2002) and an ABI 7500 RT-PCR System ${ }^{\circledR}$ (Applied Biosystems, CA, USA). To avoid amplification inhibition and increase the reaction sensitivity, the samples were analysed in duplicates with 10-fold dilutions of the nucleic acid. A standard curve was constructed from HAdV41 DNA that was cloned into pBR322 (kindly donated by R Girones, Barcelona University).

\section{RESULTS}

As shown in Table, nested-PCR of the digestive tissue samples indicated that the HAdV5 genome was present during the entire depuration process $(0 \mathrm{~h}, 48 \mathrm{~h}, 72 \mathrm{~h}$ and $96 \mathrm{~h}$ ), while the HAV genome was present up to $72 \mathrm{~h}$ $(0 \mathrm{~h}, 48 \mathrm{~h}$ and $72 \mathrm{~h})$. HAdV could be detected after $96 \mathrm{~h}$ by nested-PCR in the water from the depuration tank (1 positive sample out of 3 ).

To evaluate the viral viability, cell monolayers were inoculated with the oyster samples at non-cytotoxic dilutions (1:4 for cell line FRhK-4, 1:8 for cell line HEP-2 and 1:2 for cell line A549); the viral nucleic acid was subsequently extracted from the cellular supernatants to quantify the number of infectious viral particles. ICCPCR assays were performed with the Hep-2 and FRhK-4 cells and the results indicate that the viruses were inactivate after $96 \mathrm{~h}$ of seawater recirculation and UV radiation. For HAV, viral inactivation was reached within $72 \mathrm{~h}$ of depuration. However, for the complete inactivation of HAdV5, $96 \mathrm{~h}$ of water recirculation under UV radiation was required (Table).

To confirm the ICC-PCR results for HAdV5 infectivity, all of the samples were tested with IFA performed on A549 cells. According to Fig. 1, the virus was viable up until $72 \mathrm{~h}$ of oyster depuration. As shown in Fig. 1 and Table, $96 \mathrm{~h}$ of depuration were necessary to completely inactivate HAdV5 and HAV.

The quantification of HAdV5 using qPCR in the different oyster tissues submitted to bioaccumulation and depuration for $48 \mathrm{~h}, 72 \mathrm{~h}$ and $96 \mathrm{~h}$ was expressed in genome copies per gram $(\mathrm{GC} / \mathrm{g})$. The mean data from three independent experiments were graphed versus their corresponding sampling times (t) with the GraphPad Prism 5 software. As shown in Fig. 2, the HAdV5 genome was detected in the tissue samples after $96 \mathrm{~h}$ of depuration. The initial bioaccumulation concentration $\left(\sim 5 \times 10^{5}\right.$ $\mathrm{GC} / \mathrm{g}$ ) was greater than the final concentration in all of the tissues $\left(1.8 \times 10^{5}\right.$ for gills, $1.6 \times 10^{5}$ for digestive tissue, $3.4 \times 10^{4}$ for haemolymph, $8.7 \times 10^{4}$ for mantle and $4.3 \times 10^{4}$ for labial palps) where the final values were decreased by approximately $1 \log$.

\section{DISCUSSION}

Our research group previously demonstrated that depuration effectively inactivated Salmonella typhimurium from oysters that were artificially contaminated. Specifically, the oysters were decontaminated when UV radiation and chlorine treatment were employed for at least $12 \mathrm{~h}$ of depuration (Corrêa et al. 2007). The combination of chlorine and UV radiation increased the efficiency of disinfection and decreased the time required to complete the depuration process. The two disinfection

TABLE

Results of human adenovirus type 5 (HAdV5) and hepatitis A virus (HAV) detection in gastrointestinal tracts of oysters and seawater samples after bioaccumulation and ultraviolet radiation disinfection obtained in three independent experiments evaluated by nested-polymerase chain reaction (PCR), integrated cell culture-PCR (ICC-PCR) and immunofluorescence assay (IFA)

\begin{tabular}{|c|c|c|c|c|c|}
\hline $\begin{array}{l}\text { Depuration times } \\
\text { (h) }\end{array}$ & Nested-PCR HAV ${ }^{a}$ & $\begin{array}{c}\text { ICC-PCR } \\
\mathrm{HAV}^{a}\end{array}$ & $\begin{array}{l}\text { Nested-PCR } \\
\text { HAdV5 }^{a}\end{array}$ & ICC-PCR HAdV5 ${ }^{a}$ & $\begin{array}{c}\text { IFA } \\
\text { HAdV5 }^{a}\end{array}$ \\
\hline \multicolumn{6}{|c|}{ Oyster samples } \\
\hline 0 & $3 / 3$ & $3 / 3$ & $3 / 3$ & $3 / 3$ & $3 / 3$ \\
\hline 48 & $3 / 3$ & $2 / 3$ & $3 / 3$ & $3 / 3$ & $3 / 3$ \\
\hline 72 & $1 / 3$ & $0 / 3$ & $3 / 3$ & $3 / 3$ & $3 / 3$ \\
\hline 96 & $0 / 3$ & $0 / 3$ & $3 / 3$ & $0 / 3$ & $0 / 3$ \\
\hline \multicolumn{6}{|c|}{ Water samples } \\
\hline 96 & $0 / 3$ & $0 / 3$ & $1 / 3$ & - & - \\
\hline
\end{tabular}

$a$ : fractions indicate the number of positive samples per three samples tested. 
methods likely have a synergistic effect because they inflict different types of damage on the microorganisms (Koivunen \& Heinonen-Tanski 2004). Chlorine has been historically used in depuration tanks to disinfect oysters, although its effectiveness during the depuration process is only marginal because it is toxic to the shellfish as well. According to Rodrick and Schneider (2003), low levels of chlorine impair shellfish pumping and hamper shellfish depuration. In contrast, UV radiation eliminates enteric bacteria, viruses, bacterial and protozoan spores in the water without the production of toxic byproducts or other chemical residues. UV radiation has been widely used to disinfect groundwater and wastewater and has been evaluated against many viral pathogens, such as HAV and poliovirus (Gerba et al. 2002, Hijnen et al. 2006). To produce safe natural seafood and ensure customer safety, as well as the sustainable development of high quality resources and production, the depuration process must be improved to eliminate potential shellfish contamination. In this study, we used the same depuration process previously described to assess its ability to decontaminate oysters that were artificially infected with HAV and HAdV5. This paper is the first report to describe the use of UV radiation for oyster depuration in Brazil. UV irradiation is a good method for water disinfection because it does not induce physiological damage to the shellfish, nor does it damage the surrounding environment. However, the time required to eliminate viral pathogens from oysters during depuration is much greater compared to bacterial depuration. According to Love et al. (2010), after $44 \mathrm{~h}$ of depuration, HAV and poliovirus were depurated from oysters and hard shell clams at a slower rate than E. coli and Enterococcus faecalis. Thus, bacteria are purified more quickly and may be potentially cleared by different mechanisms than human enteric viruses; therefore, monitoring bacterial infection is a poor indicator of viral contamination of depurated shellfish. There is evidence that some viral pathogens may be more resistant to environmental conditions and sewage or water treatment processes compared to bacterial organisms (Mena \& Gerba 2009).

Several reports have previously described the use of molecular methods to evaluate enteric virus contamination in oysters (Rigotto et al. 2005, Sincero et al. 2006). However, these methods are limited because genome detection by enzymatic amplification does not always accurately predict the contamination risk. Several bivalve depuration studies reported the use of PCR to evaluate purification dynamics (Formiga-Cruz et al. 2003, Ueki et al. 2007), but only some of the studies mention using cell culture to evaluate the persistence of viral infectivity (Kingsley \& Richards 2003, Choo \& Kim 2006, Hernroth \& Allard 2007, Love et al. 2010). However, when viable enteric viruses are isolated from oysters, they maintain their ability to infect permissive cells lines in vitro (Rigotto et al. 2005). Cell culture infectivity can be a useful tool to study viral viability in molluscs, although cell culture methods are more laborious. However, using a combination of both molecular and cell culture methods allows for a more accurate evaluation of viral elimination. Kingsley and Richards (2003) previously reported that HAV was present in artificially contaminated Crassostrea virginica oysters (after $16 \mathrm{~h}$ of exposure) over a six-week period of depuration, when analysed by RT-PCR. However, when cell culture methods were applied, the HAV was only infectious for up to three weeks; these results confirm the importance of using both cell culture assays and molecular methods to completely evaluate shellfish viral contamination.

Our nested-PCR results indicate that the HAdV5 and HAV genomes were present for up to $96 \mathrm{~h}$ and $72 \mathrm{~h}$, respectively, after bivalve depuration with UV light radiation and water disinfection.

In this study, the HAdV5 genome could be detected in all of the oyster samples that were analysed with nested-PCR and qPCR. However, according to the ICC-PCR and IFA results, only some virus genomes were detected by direct PCR. PCR and qPCR DNA detection of non-viable viruses may give a false positive result because the viral genome may be inactivated by UV radiation and may be re-ingested or bioaccumulated by the molluscs; our data indicate that the HAdV5 viral genome could be detected via PCR for up to $96 \mathrm{~h}$ of depuration. Despite
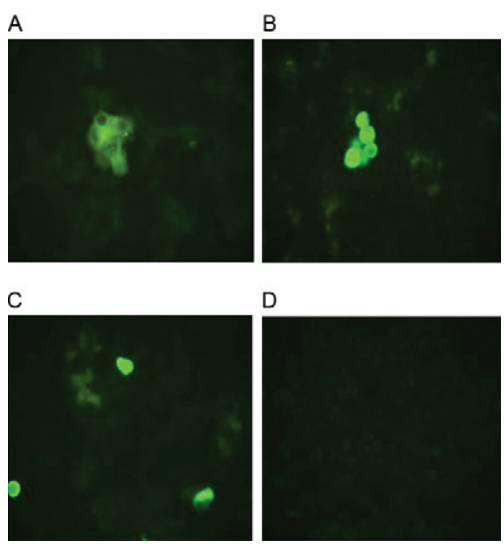

Fig. 1: detection of human adenovirus type 5 by indirect immunofluorescence in a monolayer of A549 cells inoculated with oyster tissue extracts after depuration in different times $(0 \mathrm{~h}, 48 \mathrm{~h}, 72 \mathrm{~h}$ and $96 \mathrm{~h})$ (A, B, C, D, respectively).

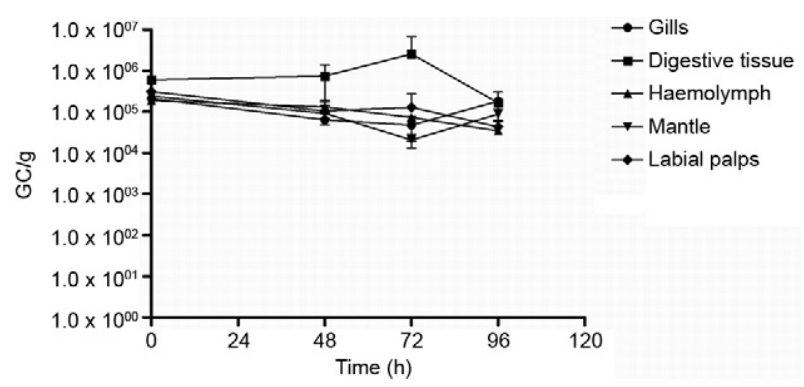

Fig. 2: human adenovirus type 5 genome reduction in different oyster tissues after depuration in different times ( $0 \mathrm{~h}, 48 \mathrm{~h}, 72 \mathrm{~h}$ and $96 \mathrm{~h})$. Each data point is an average of three independent experiments analyzed by quantitative-polymerase chain reaction \pm standard deviation. GC/g: genome copies per gram. 
partial virus genome degradation, molecular methods such as qPCR may still react with degraded DNA, resulting in false positive results.

As it is expected for depuration with UV disinfection, the HAV and HAdV5 viruses were negative in the infectivity assays, both in the circulated water and within oysters. These results agree with the data previously published by Love et al. (2010), where they observed a $98.5 \%$ decrease in viral infectivity from oysters after $44 \mathrm{~h}$ of depuration in a flow-through system.

Several studies have reported that adenoviruses are more resistant to UV radiation than other doublestranded DNA and single-strand RNA viruses (Mena $\&$ Gerba 2009). It has been suggested that viruses with double-stranded genomes are less susceptible to UV inactivation because the virus can still replicate via the second strand if only one strand is damaged (ThurstonEnriquez et al. 2003).

This paper is the first report to describe the depuration dynamics of viral pathogens in oysters using a closed system in the country of Brazil. Most countries that produce bivalve molluscs for export strictly regulate and monitor depuration systems and operating procedures to ensure the quality control of the purification process. Monitoring the temperature and salinity of the water during the purification cycle is also recommended (European Communities 1992). The Brazilian legislation currently does not regulate depuration systems and only the presence of bacteria, such as faecal coliform and Salmonella sp., in water cultures and mollusc meat are regulated (ANVISA 2001, CONAMA 2005).

The UV/chlorine purification system studied here was effective in purifying oysters that were artificially infected with HAdV5 and HAV. The treatment effectively eliminated viral contamination after $96 \mathrm{~h}$ of depuration, as determined by ICC-PCR and IFA. According to these results, it is possible to observe a differential elimination of HAdV5 and HAV from oysters in relation to the purification time. Moreover, these data confirm that HAdV is more UV-resistant compared to HAV and, therefore, requires longer periods of UV exposure for viral inactivation.

\section{ACKNOWLEDGEMENTS}

To Blue Water Aquaculture, for the depuration system, to Dr Rosina Gironés and Dr Sílvia Bofill, University of Barcelona, for their kind review of this manuscript, and to Dr João Batista Calixto, Federal University of Santa Catarina, for allowing the use of the quantitative PCR machine.

\section{REFERENCES}

Allard A, Albinsson B, Wadell G 2001. Rapid typing of human adenoviruses by a general PCR combined with restriction endonuclease analysis. J Clin Microbiol 39: 498-505.

ANVISA - Agência Nacional de Vigilância Sanitária 2001. Resolução 12. Available from: anvisa.gov.br/legis/resol/12_01rdc.htm>.

Barardi CRM, Yip H, Emslie KR, Vesey G, Shanjer RS, Williams KL 1999. Flow cytometry and RT-PCR for rotavirus detection in artificially seeded oyster meat. Int J Food Microbiol 49: 9-18.

Boom R, Sol CJA, Salimans MMM, Jansen CL, Werthein-Van Dillen PME, Noordaa J 1990. Rapid simple method for purification of nucleic acids. J Clin Microbiol 28: 495-503.
Choo YJ, Kim SJ 2006. Detection of human adenoviruses and enteroviruses in Korean oysters using cell culture, integrated cell culture-PCR and direct PCR. J Microbiol 44: 162-170.

CONAMA - Conselho Nacional do Meio Ambiente 2005. Resolution 357. Available from: mma.gov.br/port/conama/res/res05/ res35705.pdf.

Corrêa AA, Albarnaz JD, Moresco V, Poli CR, Teixeira AL, Simões CMO, Barardi CRM 2007. Depuration dynamics of oysters (Crassostrea gigas) artificially contaminated by Salmonella enterica serovar Typhimurium. Mar Environ Res 63: 479-489.

Croci L, Losio MN, Suffredini E, Pavoni E, Di Pasquale S, Fallacara F, Arcangeli G 2007. Assessment of human enteric viruses in shellfish from the northern Adriatic Sea. Int J Food Microbiol 114: 252-257.

de Paula VS, Lu L, Niel C, Gaspar AM, Robertson BH 2004. Genetic analysis of hepatitis A virus isolates from Brazil. J Med Virol 73: 378-383.

European Communities 1992. Council Directive of 15th of July 1991 laying down the health conditions for the production and placing on the market of live bivalve mollusks (91/492/EEC). Official Journal of European Communities 268: 1-14.

Fleming LE, Broad K, Clement A, Dewailly E, Elmir S, Knap A, Pomponi SA, Smith S, Gabriele H, Walsh P 2006. Oceans and human health: emerging public health risks in the marine environment. Mar Pollut Bull 53: 545-560.

Formiga-Cruz M, Allard AK, Conden-Hansson AC, Henshilwood K, Hernroth BE, Jofre J, Lees DN, Lucena F 2003. Evaluation of potential indicators of viral contamination in shellfish and their applicability to diverse geographical areas. Appl Environ Microbiol 69: 1556-1563.

Gerba CP, Gramos DM, Nwachuku N 2002. Comparative inactivation of enteroviruses and adenovirus 2 by UV light. Appl Environ Microbiol 68: 5167-5169.

Hernroth B, Allard A 2007. The persistence of infectious adenovirus (type 35) in mussels (Mytilus edulis) and oysters (Ostrea edulis). Int J Food Microbiol 113: 296-302.

Hernroth BE, Conden-Hansson AC, Rehnstam-Holm AS, Girones R, Allard AK 2002. Environmental factors influencing human viral pathogens and their potential indicator organisms in the blue mussel, Mytilus edulis: the first Scandinavian report. Appl Environ Microbiol 68: 4523-4533.

Hijnen WAM, Beerendonk EF, Medema GJ 2006. Inactivation credit of UV radiation for viruses, bacteria and protozoan (oo)cysts in water: a review. Water Res 40: 3-22.

Jothikumar NKG, Hill VR, Sobsey MD 2005. Rapid detection of infectious adenoviruses by mRNA real-time RT-PCR. $J$ Virol Methods 127: 148-153.

Katayama H, Shimasaki A, Ohgaki S 2002. Development of a virus concentration method and its application to detection of enterovirus and norwalk virus from coastal seawater. Appl Environ Microbiol 68: 1033-1039.

Kingsley DH, Richards GP 2003. Persistence of hepatis A virus in oysters. J Food Prot 66: 331-334.

Ko G, Jothikumar N, Hill VR, Sobsey MD 2005. Rapid detection of infectious adenoviruses by mRNA real-time RT-PCR. $J$ Virol Methods 127: 148-153.

Koivunen J, Heinonen-Tanski H 2004. Inactivation of enteric microorganisms with chemical disinfectants, UV irradiation and combined chemical/UV treatments. Water Res 39: 1519-1526.

Love DC, Lovelace GL, Sobsey MD 2010. Removal of Escherichia coli, Enterococcus fecalis, coliphage MS2, poliovirus and 
hepatitis A virus from oysters (Crassostrea virginica) and hard shell clams (Mercinaria mercinaria) by depuration. Int $J$ Food Microbiol 14: 211-217.

Mena KD, Gerba CP 2009. Waterborne adenovirus. Rev Environ Contamin Toxicol 198: 133-167.

Murchie LW, Cruz-Romero M, Kerry JP, Linton M, Patterson MF, Smiddy M, Kelly AL 2005. High pressure processing of shellfish: a review of microbiological and other quality aspects. Innovat Food Sci Emerg Techl 6: 257-270.

Myrmel EMM, Berg E, Rimstad A, Grinde B 2004. Detection of enteric viruses in shellfish from the Norwegian coast. Appl Environ Microbiol 70: 2678-2684.

Oliveira-Neto FM 2005. Diagnóstico do cultivo de moluscos em Santa Catarina, Epagri, Florianópolis, 60 pp.

Reed LJ, Muench H 1938. A simple method of estimating fifty percent endpoints. Am J Trop Med Hyg 27: 483-497.

Richards GP, Mcleod C, Le Guyader SF 2010. Processing strategies to inactivate enteric viruses in shellfish. Food Environ Virol 2: 183-193.
Rigotto C, Sincero TC, Simdes CMO, Barardi CRM 2005. Detection of adenoviruses in shellfish by means of conventional PCR, nested-PCR and integrated cell culture PCR (ICC/PCR). Water Res 39: 297-304.

Rodrick GE, Schneider KR 2003. Molluscan shellfish depuration. In A Villaboa, B Reguera, J Romalde, R Reis, Proceedings of the $4^{\text {th }}$ International Conference on Molluscan Shellfish Safety, Santiago de Compostela, Spain, 2002.

Sincero TCM, Levin DB, Simões CMO, Barardi CRM 2006. Detection of hepatitis A virus (HVA) in oysters (Crassostrea gigas). Water Res 40: 895-902.

Thurston-Enriquez JA, Haas CN, Jacangelo J, Gerba CP 2003. Chlorine inactivation of adenovirus type 40 and feline calicivirus. Appl Environ Microbiol 69: 3979-3985.

Ueki Y, Shoji M, Suto A, Tanabe T, Okimura Y, Kikuchi Y, Saito N, Sano D, Omura T 2007. Persistence of caliciviruses in artificially contaminated oysters during depuration. Appl Environ Microbiol 73: $5698-5701$

Wang D, Wu Q, Kou X, Yao L, Zhang J 2008. Distribution of norovirus in oyster tissues. $J$ Appl Microbiol 105: 966-1972. 